\title{
RESEARCH PAPER \\ ACADEMIC PERFORMANCE OF LESS ENDOWED HIGH SCHOOL STUDENTS IN THE KWAME NKRUMAH UNIVERSITY OF SCIENCE AND TECHNOLOGY
}

\author{
H. M. Yusif ${ }^{1}$ and B. Ali $^{2}$ \\ KNUST, Kumasi \\ ${ }^{I}$ Corresponding author,e-mail: hadraty@yahoo.co.uk
}

\begin{abstract}
This paper investigates the academic performance of students from less endowed senior high schools in the Kwame Nkrumah University of Science and Technology (KNUST). Questionnaires were administered to 152 (123 males and 29 females) fourth year students who enrolled for various programmes at KNUST in 2007 through the less endowed admission policy. The items included in the questionnaires were student characteristics (e.g. age, gender, university entrance score, number of siblings) and parental characteristics (e.g. educational attainments and occupation). We found that $61.8 \%$ were high performing students (11.8\% first class and $50 \%$ second class upper). We also found that among the less endowed socio-economic group, university entrance score had a significant positive influence on their academic performance at $5 \%$ level of significance. Again, it was discovered that if parental factors were not controlled for, being male had a significant positive influence on the performance of less endowed students at $5 \%$ significance level. These findings have very important policy implications for Ghana, especially policies aimed at improving participation of students from less endowed schools in public universities.
\end{abstract}

Keywords: Performance, less endowed, student, admission, university

\section{INTRODUCTION}

Little theory, economic or otherwise, is currently available to describe the determinants of educational achievements (Summers and Wolfe, 1977). However, it has been documented that performance at university entrance examination has a positive and significant effect on performance in university examinations (Johnes, 1997; Robst \& Keil, 2000; Smith \& Naylor, 2005; Birch \& Miller, 2006; and Birch
\& Miller, 2007). As a result, public university authorities in Ghana have used academic achievement in the national examination conducted at the end of the final year in the senior high school (SHS) as the sole criterion for selecting students for the various programmes in the highly subsidized public universities.

Currently, there are eight public universities in Ghana and the two topmost ones, in terms of 


\section{Yusif and Ali}

enrolment, are the University of Ghana (UG) and the KNUST. In the 1998/1999 and $1999 / 2000$ academic years between $60 \%$ and $92 \%$ of students admitted for the various degrees in the UG were from the top 50 SHSs constituting about $10 \%$ of the secondary schools in the country at that time (504 secondary schools). Similarly, at the KNUST, the top 50 schools formed about $75 \%$ of admissions during the same period (Addae-Mensah, 2000). Indeed, some of the less endowed schools in the country had never produced a single candidate who had gained admission into the public universities. This serious imbalance in university entry might be explained by the fact that, admission to public universities were highly competitive due to the existing facilities and, therefore, students with the best results from the less endowed schools could not compete even with average students from the well endowed schools for the few places in the universities. This is not surprising on the grounds that one of the major predictors of success in Ghanaian secondary schools is quality of school attended (Yusif et al., 2011; Addae-Mensah, 2000).

It was thus, thought that the university education system was unfair and likely to perpetuate the existing social and economic inequalities in the country since the top 50 schools were and are attended primarily by children from wealthier and/or well educated families (Yusif et al., 2011; Atuahene, 2006). These children from wealthier and/or educated families were likely to get hold of the lucrative and well paid jobs and they would command respectable status in the Ghanaian society as compared to children from disadvantaged families. This is derived from the fact that educational attainment and the extent to which an individual participates in the educational system is, perhaps, one of the single most important factors in the determination of lifetime economic and social attainment (McIntosh and Munk, 2007). In the Ghanaian context inter generational poverty would be deepened and public universities in Ghana, which are heavily subsidized by government, would be failing to play their role as tools for social mobility. In fact, the government of Ghana provides over $75 \%$ of the finances of public universities in the country (Adu and Opoku-Afriyie, 2002).

To address this serious imbalance in public university entry and ensure that equity in the public university education system is improved, authorities at the KNUST introduced the less endowed admission policy in 2003. This admission policy allows all SHS classified as less endowed (297 out of about 600 SHS in 2002) to select the top six students (i.e. 3 boys and 3 girls) who obtained the basic requirements for courses that they qualified at the KNUST to be offered admission. Between 2003 and 2010, about 1,948 students comprising 1,423 males and 525 females, from less endowed schools had the opportunity to enrol in the university. Other public universities have also admitted less endowed students since 2003.

However, not much is known about the university academic performance of these students from less endowed schools with comparatively lower university entrance scores. Thus, the less endowed admission policy at KNUST has provided a natural experiment to be exploited. Indeed, it is crucial to empirically examine the statistical basis for this seemingly equity and pro-poor admission policy. Knowledge of the academic performance of this group of students will be very useful for policy makers as well as university authorities regarding the redesigning of university admissions policy in the country to capture non-traditional students (students from less endowed schools). Again, knowledge of the performance of less endowed students in the public universities is very important for the Ghanaian public.

The goal of this paper is to examine the academic performance of students from less endowed SHS in the KNUST. The selection of KNUST is for two reasons. First, KNUST is the only public university in the country that has a very clear policy regarding admission of stu- 
Academic performance of students from less endowed senior high ... 106

dents from less endowed schools. Second, less endowed students in KNUST have similar characteristics as their socio-economic group members in the other public universities in the country. They are mostly children from disadvantaged families. Past studies on university students' performance in the industrialized countries (Johnes, 1997; Win and Miller, 2005; Smith and Naylor, 2005; and Birch and Miller, 2006) have reported that prior academic achievement predicted students' university academic performance.

Certainly, this study will enable us find out whether university authorities were justified in offering places to students from less endowed schools at the expense of more qualified students or even at the expense of students from wealthier homes who had qualified and were prepared to pay fees.

\section{Types of students in Ghanaian public uni- versities}

To analyze the performance of less endowed students, we point out the various paths of admission of students in Ghanaian public universities. The first category of students is termed as regular students and they constitute about $70 \%$ of the total admission. Under this, each department is given a quota by the university's Academic Board and applicants are selected solely on the basis of their performance in the West African Senior School Certificate Examination (WASSCE). Regular students are largely sponsored by central government and so they only pay academic facility user fees.

The second group comprise matured students and they are candidates aged 25 years or above and have worked for not less than two years. They write a competitive entrance examination organized by the various Departments. Candidates who pass the entrance examination are invited for interview and the required number is then selected by the Departments. Matured students are also sponsored by central government and the number admitted depends on the quota given by the Academic Board. The third group are those admitted as protocol and staff children. Data from the Planning Unit, KNUST reveal that, the number admitted through the protocol and staff children admission path did not exceed $10 \%$ of the total admission from 2003 to 2012.

The fourth group are the fee paying students and they consist of local and foreign students. The local fee paying students are Ghanaians who have at least the basic requirement for a particular programme but due to competition could not meet the cut-off point. This group of students pay tuition fees. Together with foreign students, fee paying students do not exceed $15 \%$ of total admissions every year. They must demonstrate that they have the resources to pay full fees.

Finally, there are the less endowed students who formed about 3\% (216) of total enrolment of 7,333 in the 2009/2010 academic year in KNUST (Basic Statistics, 2010). They are admitted under the less endowed admission (LEA) policy. To qualify for this type of admission a candidate must first be a student from a less endowed school and second he/she must have at least the basic requirement, which is an aggregate not exceeding 24 with credits in English language, Mathematics and Integrated Science. The less endowed schools are mainly located in deprived communities and lack basic facilities. These facilities include classrooms, potable water, electricity, as well as trained and experienced teachers. In 2002 out of the roughly 600 secondary schools in the country, 297 forming about 49.5\%, were classified as less endowed (Ghana Education Service files, 2011). This number has since not changed even though the number of SHS increased to about 697 in 2009. The less endowed schools are associated with students from disadvantaged families or those from rural communities and in most cases a large proportion of them are less prepared for university entry. It should be noted that many less endowed schools are even unable to supply students who have the basic requirements to enable them benefit from the 
107 Yusif and Ali

LEA policy.

\section{Analysis of Less endowed students' admis-} sion

This section is about students who benefitted from the LEA policy since its introduction in 2003 and Table 1 presents the yearly admission and enrolment figures.

Data in Table 1 indicate that out of the total of 2,850 students admitted between 2003 and 2010, only 1,948 students constituting about $68.4 \%$ actually enrolled. This might be explained by three important factors

- Many students in the less endowed schools are from very poor homes in the rural areas. Thus, students and their parents are simply unable to raise the needed minimum funds to register and feed themselves at the university.

- Many of the less endowed schools are in rural areas and given the poor penetration of the postal system in Ghana, many admission letters are delayed. By the time the admission letters are received, there is very little time left for students and their parents to mobilize the needed funds to pay for the registration fees, academic facility user fees, lodging and other charges.

- Some of the less endowed students might prefer enrolling in teacher training colleges or nursing training schools to the university for several reasons including cost of training in the university.

Regarding students who enrolled, the data indicate that the number increased from 46 in 2003 to 534 in 2005 . However, in 2006 enrolment declined significantly by about $37.3 \%$ to 335 . The significant decline in enrolment from a high of 534 in 2005 to a low of 149 in 2008 was due to two main factors. First is the general reduction in admissions in KNUST due to complaints by some lecturers about very large class sizes and increased workloads. Second is the inability of students in many less endowed schools to meet the basic admission requirements. Indeed, the strategic objective of the university authorities had been to increase enrolment of deprived students to 1,000 each academic year but it is apparent that this strategic objective might not be achieved in the very near future.

Table 1: Less-endowed students: 2003-2010

\begin{tabular}{ccccccc}
\hline & \multicolumn{2}{c}{ Male } & \multicolumn{2}{c}{ Female } & \multicolumn{2}{c}{ Total } \\
Year & Admitted & Enrolled & Admitted & Enrolled & Admitted & Enrolled \\
\hline 2003 & - & 32 & - & 14 & - & 46 \\
2004 & 238 & 186 & 91 & 70 & 329 & 256 \\
2005 & 445 & 367 & 211 & 167 & 656 & 534 \\
2006 & 358 & 252 & 149 & 83 & 507 & 335 \\
2007 & 183 & 134 & 60 & 33 & 243 & 167 \\
2008 & 176 & 114 & 63 & 35 & 239 & 149 \\
2009 & 226 & 154 & 112 & 62 & 338 & 216 \\
2010 & 387 & 184 & 151 & 61 & 538 & 245 \\
\hline
\end{tabular}

Source: Extracted from files at Planning Unit, KNUST, Kumasi 
Another striking observation is that females formed only $27 \%$ (525) of the total enrolments $(1,948)$ within the period under study. This even mask the annual differences, for example, in 2010 females formed only $24.9 \%$ of the total enrolment. The gender gap cannot be explained by the number of females in the secondary schools. A recent study about students in less endowed schools reported that out of the total sample of 240, females constituted $46.3 \%$ (Yusif et al. 2011). This suggests that the under -representation of females in this admission path can only be explained by the relatively poor performance of female students compared to males in the deprived schools. This appears to confirm the finding that a boy is more likely to perform better than a girl in the final SHS examination (Yusif et al., 2011).

With regards to the distribution of students among various programmes in the university we find that the Department of Economics alone accepted the highest number of less endowed students. In 2007, the department admitted 21 less endowed students which formed about $12.6 \%$ of total less endowed students who enrolled. This exceeds that of the total less endowed admission for the College of Health and Allied Sciences by about 50\% and also exceeds College of Engineering by about $14 \%$ (The Planning Unit, 2010). Perhaps attempts could be made to increase the number of less endowed students admitted into science based programmes, if possible.

\section{METHODOLOGY}

In this section, the sources of data, variables description, descriptive analysis and the model used for our regression analysis are presented.

\section{Sources of Data}

This paper used two main datasets obtained from the KNUST to examine the academic performance of less endowed students in the University. The first dataset was obtained from the 2007 cohort of less endowed students. A total of 243 students were admitted but 167 enrolled. Of the 167 that enrolled, 152 were in the fourth year, seven had been withdrawn, four had deferred and four repeated. Questionnaires were administered to the 152 in year 4 . In total, 105 (86 males and 19 females) respondents, constituting roughly $69 \%$ returned the completed forms.

The questionnaires included covariates for student, father and mother characteristics. The student characteristics included gender, age, number of siblings, or friends who have completed university, birth order, number of wives father has, and university entrance score -i.e. aggregate of WASSCE that a candidate entered KNUST with. About parental background, the variables of interest were employment status, educational attainments and occupation.

The second dataset obtained from college examination officers included cumulative weighted average (CWA) for each of the 152 students who enrolled and were in year 4 . We did not depend on students' survey for the CWA because it has the tendency of overestimating actual performance (Grove et al., 2006). These two sets of data were then merged and the process yielded a sample of 105 as some respondents did not return the forms for personal and parental background information.

\section{Description of Variables}

The dependent variable was the CWA of respondents. The CWA has been used as a measure of students' performance and in KNUST it could range from $0.00-100.00$. A CWA between 50.00-100.00 indicates success. However, CWA between 45.00-49.99 is mere Pass whilst that between $0.00-44.99$ is Fail. Usually, students who obtain CWA less than 40.00 at the end of the first year are withdrawn from the programme.

The explanatory variables of interest were grouped into three - first is student characteristics comprising age, gender, family size (number of siblings), university entrance score, and number of wives of father. Second is father's characteristics which include educational 


\section{Yusif and Ali}

attainment, occupation and present job status. The third is mother's characteristics and consist of educational attainment, occupation and job status.

\section{Descriptive analysis}

Tables 2, 3 and 4 contain description of the 105 students who returned the completed forms. The description is of substantial public policy interest in terms of the gender of student, relation a student lives with, number of siblings and region of origin.
Data in Table 2 reveal that $47.6 \%$ of the sampled students live with their fathers and mothers (50 out of the total 105 students), whilst $27.6 \%$ live with their mothers only. About 20\% live with other relations. Also, $73.3 \%$ had four or more siblings indicating that many of them had big family sizes. Roughly, $87.6 \%$ of the respondents were the first in their individual families to pursue university education even though only $20 \%$ were first born children. This is an indication that the LEA policy had made significant contribution to improving the lives

Table 2: Description of students' characteristics

\begin{tabular}{|c|c|c|c|c|c|}
\hline $\begin{array}{l}\text { VARIABLE } \\
\text { Student characteristics }\end{array}$ & DESCRIPTION & CATEGORY & & & \\
\hline Gender & Gender of respondent & $\begin{array}{l}0=\text { Male } \\
1=\text { Female }\end{array}$ & 19 & $\begin{array}{l}\mathbf{M} \\
86\end{array}$ & $\begin{array}{l}\text { Total } \\
86 \\
19\end{array}$ \\
\hline Relation & $\begin{array}{l}\text { Relation respondent lives } \\
\text { with }\end{array}$ & $\begin{array}{l}1=\text { Father and mother } \\
2=\text { father only } \\
3=\text { mother only } \\
4=\text { other relation }\end{array}$ & $\begin{array}{l}9 \\
1 \\
5 \\
4\end{array}$ & $\begin{array}{l}41 \\
4 \\
24 \\
17\end{array}$ & $\begin{array}{l}50 \\
5 \\
29 \\
21\end{array}$ \\
\hline Siblings & $\begin{array}{l}\text { Number of siblings of } \\
\text { respondent }\end{array}$ & $\begin{array}{l}1=\text { One } \\
2=\text { Two } \\
3=\text { Three } \\
4=\text { Four or more } \\
0=\text { single child }\end{array}$ & $\begin{array}{l}1 \\
1 \\
3 \\
13 \\
1\end{array}$ & $\begin{array}{l}3 \\
6 \\
12 \\
64 \\
1\end{array}$ & $\begin{array}{l}4 \\
7 \\
15 \\
77 \\
2\end{array}$ \\
\hline Birth Order & Birth order of respondent & $\begin{array}{l}1=\text { first born } \\
2=\text { second born } \\
3=\text { third born } \\
4=\text { fourth or other }\end{array}$ & $\begin{array}{l}3 \\
2 \\
6 \\
8\end{array}$ & $\begin{array}{l}18 \\
21 \\
17 \\
30\end{array}$ & $\begin{array}{l}21 \\
23 \\
23 \\
38\end{array}$ \\
\hline University & Siblings in university & $\begin{array}{l}1=\text { yes } \\
0=\text { no }\end{array}$ & $\begin{array}{l}2 \\
17\end{array}$ & $\begin{array}{l}11 \\
75\end{array}$ & $\begin{array}{l}13 \\
92\end{array}$ \\
\hline Origin & Region of origin & $\begin{array}{l}1=\text { Ashanti } \\
2=\text { Brong Ahafo } \\
3=\text { Central } \\
4=\text { Eastern } \\
5=\text { Greater Accra } \\
6=\text { Northern } \\
7=\text { Upper East } \\
8=\text { Upper West } \\
9=\text { Volta } \\
10=\text { Western }\end{array}$ & $\begin{array}{l}5 \\
0 \\
3 \\
5 \\
1 \\
2 \\
0 \\
0 \\
3 \\
0\end{array}$ & $\begin{array}{l}12 \\
11 \\
13 \\
17 \\
2 \\
3 \\
2 \\
2 \\
20 \\
4\end{array}$ & $\begin{array}{l}17 \\
11 \\
16 \\
22 \\
3 \\
5 \\
2 \\
2 \\
23 \\
4\end{array}$ \\
\hline TOTAL & & & 19 & 86 & 105 \\
\hline
\end{tabular}


Academic performance of students from less endowed senior high ... 110

of some disadvantaged families - at least one member had enrolled and was about to complete university.

With respect to regional distribution, Volta and Eastern regions formed about 23\% and 21\% respectively of those who enrolled. This is not surprising because of the 297 less endowed schools in 2002, Volta had 50, followed by Eastern, 49. However, four regions, i.e. Greater Accra, Northern, Upper East and Upper West constituted about $11.4 \%$ of the students who enrolled. It should be noted that the basis for LEA is the ability of students to meet the basic requirements for university admission.

In Ghana, two of the most important indicators of poverty that the researchers used are low educational qualification, i.e. JHS qualification or none and farming (Ghana Statistical Service, 2007; Thomas et al., 2001). Table 3 shows that $46.7 \%$ of fathers had JHS qualification or none and $31.4 \%$ were farmers. Curiously, $21.9 \%$ were deceased. With regards to mothers, Table 4 shows that $77.1 \%$ had JHS qualification or none, about $22.9 \%$ were farmers while traders formed $56.2 \%$.

Based on the analysis above, it is obvious that a large proportion of the sampled students was from credit constrained families. This is because $73.3 \%$ had four or more siblings (big family size), $77.1 \%$ of their mothers and $46.7 \%$ of fathers had JSS qualification or none, $31.4 \%$ of the fathers were farmers, $79 \%$ of mothers were traders or farmers and $21.9 \%$ of fathers were deceased. As explained earlier, in Ghana

Table 3: Description of fathers' characteristics

\begin{tabular}{|c|c|c|c|c|c|}
\hline Father characteristics & & & $\mathbf{F}$ & $\mathbf{M}$ & Total \\
\hline Education & Last school father attended & $\begin{array}{l}1=\text { University } \\
2=\text { Poly } / \text { NTC } / \mathrm{TTC} \\
3=\mathrm{SHS} / \mathrm{OL} \\
4=\mathrm{JHS} \text { or none } \\
5=\text { Other }\end{array}$ & $\begin{array}{l}2 \\
11 \\
1 \\
5 \\
0\end{array}$ & $\begin{array}{l}5 \\
22 \\
12 \\
44 \\
3\end{array}$ & $\begin{array}{l}7 \\
33 \\
13 \\
49 \\
3\end{array}$ \\
\hline Status & Status of father's employment & $\begin{array}{l}1=\text { working } \\
2=\text { Unemployed } \\
3=\text { Retired } \\
4=\text { deceased }\end{array}$ & $\begin{array}{l}11 \\
2 \\
2 \\
4\end{array}$ & $\begin{array}{l}52 \\
5 \\
10 \\
19\end{array}$ & $\begin{array}{l}63 \\
7 \\
12 \\
23\end{array}$ \\
\hline Occupation & Occupation of father & $\begin{array}{l}1=\text { Senior execu- } \\
\text { tive } \\
2=\text { Professional } \\
3=\text { Junior execu- } \\
\text { tive } \\
4=\text { Trader } \\
5=\text { Farmer } \\
6=\text { Technical/ } \\
\text { clerical } \\
7=\text { Other }\end{array}$ & $\begin{array}{l}2 \\
2 \\
1 \\
3 \\
6 \\
0 \\
5\end{array}$ & $\begin{array}{l}1 \\
13 \\
4 \\
10 \\
27 \\
11 \\
20\end{array}$ & $\begin{array}{l}3 \\
15 \\
5 \\
13 \\
33 \\
11 \\
25\end{array}$ \\
\hline
\end{tabular}

Source: Authors' fieldwork, 2011

NOTE $F$ is female, $M$ is male, Poly is polytechnic, NTC is nursing training college, TTC is teacher training college, SHS is senior high school, JHS is junior high school, OL is ordinary level 


\section{Yusif and Ali}

farmers or people who have little or no education are more likely to be poorer than highly educated people or workers in the public sector.

For purposes of estimation and given the goal of this paper, the explanatory variables were limited to 21 and Table 5 presents the description of these variables. The dependent variable, as indicated earlier, is the CWA while the explanatory variables comprise gender, age, family size, ability, father's education, father's occupation, mother's education and mother's occupation. Father's and mother's education were divided into four categories: post-secondary, secondary, basic education certificate qualification or none, and other. The omitted category was other. Therefore the coefficients may be interpreted relative to this group. Father's and mother's occupation were also divided into four categories: Professional, non-professional, farming and trading. The omitted category was trading.

\section{Model specification}

Given the focus of this paper, two main models were used. The first model relied on the classification of less endowed students on the basis of their CWA. The second model involved the estimation of equation 1 specified as;

$C W A_{i}=\alpha_{0}+\alpha_{1}$ Male $_{i}+\alpha_{2}$ Age $_{i}+\alpha_{3}$ Siblings + $\alpha_{4}$ Ability $_{i}+\alpha_{5}$ Post sec $_{i}+\alpha_{6}$ Sec $_{i}+\alpha_{7}$ Bec $_{i}+\alpha_{8}$ Pr o $o_{i}+\alpha_{9}$ Npro $_{i}+\alpha_{10}$ Farm $_{i}+\alpha_{11}{\text { Post sec } 1_{i}+\alpha}$ ${ }_{12} \mathrm{Sec} 1+\alpha_{13}$ Bec $_{\mathrm{i}}+\alpha_{14} \operatorname{Pr} o 1_{i}+\alpha_{15}$ Npro $_{i}+\alpha_{16}$ Farm $_{i}+\varepsilon_{i} \ldots \ldots .1$

Where Male is a male respondent, Age is age of respondent, Siblings is the number of siblings, Ability is university entrance score, Postsec is post secondary qualification, $\mathrm{Sec}$ is secondary school qualification, $B e c$ is basic education certificate education, Pro is senior executive and professionals, Npro is junior executive, clerk, technician; and Farm is farmer/ fisherman.

Table 4: Description of mother characteristics

\begin{tabular}{|c|c|c|c|c|c|}
\hline Mother characteristics & & & $\mathbf{F}$ & $\mathbf{M}$ & Total \\
\hline Education & Last school mother attended & $\begin{array}{l}\text { 1= University } \\
2=\text { Poly } / \text { NTC/TTC } \\
3=\text { SHSCE/OL } \\
\text { 4= JHS or none } \\
5=\text { Other }\end{array}$ & $\begin{array}{l}0 \\
5 \\
2 \\
11 \\
1\end{array}$ & $\begin{array}{l}1 \\
6 \\
6 \\
70 \\
3\end{array}$ & $\begin{array}{l}1 \\
11 \\
8 \\
81 \\
4\end{array}$ \\
\hline Status & Status of mother's employment & $\begin{array}{l}1=\text { Working } \\
2=\text { Unemployed } \\
3=\text { Retired } \\
4=\text { Deceased }\end{array}$ & $\begin{array}{l}16 \\
2 \\
0 \\
1\end{array}$ & $\begin{array}{l}75 \\
7 \\
1 \\
3\end{array}$ & $\begin{array}{l}91 \\
9 \\
1 \\
4\end{array}$ \\
\hline Occupation & Occupation of mother & $\begin{array}{l}1=\text { Senior executive } \\
2=\text { Professional } \\
3=\text { Junior executive } \\
4=\text { Trader } \\
5=\text { Farmer } \\
6=\text { Technical/clerical } \\
7=\text { Other }\end{array}$ & $\begin{array}{l}0 \\
1 \\
0 \\
9 \\
5 \\
0 \\
4\end{array}$ & $\begin{array}{l}0 \\
4 \\
1 \\
50 \\
19 \\
3 \\
9\end{array}$ & $\begin{array}{l}0 \\
5 \\
1 \\
59 \\
24 \\
3 \\
13\end{array}$ \\
\hline
\end{tabular}

Source: Authors' fieldwork, 2011 
Academic performance of students from less endowed senior high ... 112

Table 5: Description of variables in the model

\begin{tabular}{|c|c|c|c|c|c|}
\hline VARIABLE & DESCRIPTION & Min & Max & Mean & SD \\
\hline $\begin{array}{l}\text { Performance } \\
C W A\end{array}$ & $\begin{array}{l}\text { Continuous variable for students' cumulative } \\
\text { weighted average }\end{array}$ & 46 & 74 & 62.78 & 5.714 \\
\hline $\begin{array}{l}\text { Gender } \\
\text { Male } \\
\text { Female }\end{array}$ & $\begin{array}{l}\text { Dummy variable for male student } \\
\text { Omitted variable }\end{array}$ & $\begin{array}{l}0 \\
0\end{array}$ & $\begin{array}{l}1 \\
1\end{array}$ & $\begin{array}{l}0.82 \\
0.18\end{array}$ & $\begin{array}{l}0.387 \\
0.387\end{array}$ \\
\hline Age & In years & 21 & 30 & 23.64 & 1.526 \\
\hline Family size & Number of siblings & 1 & 5 & 4.53 & .921 \\
\hline Ability & $\begin{array}{l}\text { Students aggregate from WASSE-SHS final } \\
\text { exam }\end{array}$ & 7 & 22 & 14.63 & 3.294 \\
\hline $\begin{array}{l}\text { Father education } \\
\text { Postsec } \\
\text { Sec } \\
\text { Bec } \\
\text { Other }\end{array}$ & $\begin{array}{l}\text { Dummy variable if father completed post sec- } \\
\text { ondary } \\
\text { Dummy variable if father completed SHS } \\
\text { Dummy variable if father completed JHS or } \\
\text { none } \\
\text { Omitted variable }\end{array}$ & $\begin{array}{l}0 \\
0 \\
0 \\
0\end{array}$ & $\begin{array}{l}1 \\
1 \\
1 \\
1\end{array}$ & $\begin{array}{l}0.38 \\
0.12 \\
0.47 \\
0.03\end{array}$ & $\begin{array}{l}0.488 \\
0.331 \\
0.501 \\
0.167\end{array}$ \\
\hline $\begin{array}{l}\text { Father occupation } \\
\text { Pro } \\
\text { Npro } \\
\text { Farm } \\
\text { Trading }\end{array}$ & $\begin{array}{l}\text { Dummy variable if father is professional } \\
\text { Dummy variable if father is non-professional } \\
\text { Dummy variable if father is farmer/fisherman } \\
\text { Omitted category }\end{array}$ & $\begin{array}{l}0 \\
0 \\
0 \\
0\end{array}$ & $\begin{array}{l}1 \\
1 \\
1 \\
1\end{array}$ & $\begin{array}{l}0.17 \\
0.39 \\
0.35 \\
0.12\end{array}$ & $\begin{array}{l}0.379 \\
0.490 \\
0.588 \\
0.331\end{array}$ \\
\hline $\begin{array}{l}\text { Mother education } \\
\text { Postsec1 } \\
\text { Sec1 } \\
\text { Bec1 } \\
\text { Other }\end{array}$ & $\begin{array}{l}\text { Dummy variable if mother completed post-sec } \\
\text { Dummy variable if mother completed SHS } \\
\text { Dummy variable if mother completed JHS or } \\
\text { none } \\
\text { Omitted variable }\end{array}$ & $\begin{array}{l}0 \\
0 \\
0 \\
0\end{array}$ & $\begin{array}{l}1 \\
1 \\
1 \\
1\end{array}$ & $\begin{array}{l}0.11 \\
0.08 \\
0.77 \\
0.08\end{array}$ & $\begin{array}{l}0.320 \\
0.267 \\
0.422 \\
0.513\end{array}$ \\
\hline $\begin{array}{l}\text { Mother occupation } \\
\text { Prol } \\
\text { Npro1 } \\
\text { Farm1 } \\
\text { Trading }\end{array}$ & $\begin{array}{l}\text { Dummy variable if mother is professional } \\
\text { Dummy variable if mother is non-professional } \\
\text { Dummy variable if father is farmer/fisherman } \\
\text { Omitted category }\end{array}$ & $\begin{array}{l}0 \\
0 \\
0 \\
0\end{array}$ & $\begin{array}{l}1 \\
1 \\
1 \\
1\end{array}$ & $\begin{array}{l}0.05 \\
0.16 \\
0.23 \\
0.56\end{array}$ & $\begin{array}{l}0.214 \\
0.370 \\
0.422 \\
0.499\end{array}$ \\
\hline
\end{tabular}

Source: Authors' fieldwork, 2011: NOTE; SD is standard deviation

This paper uses individual level data as indicated in equation 1 and a description of the variables is presented in Table 5. Indeed, some past studies (e.g. Smith and Naylor, 2001; Bratti, 2002) have exploited individual level data to address specific issues regarding students' academic performance. The advantage of using individual level data is that the potential of aggregation bias associated with models that included school level data is minimized. The approach in this paper was based on Ordinary Least Squares (OLS). Birch and Miller (2006) exploiting OLS and quantile regressions find the OLS approach to be robust. However, the limitation of the OLS is that, it does not allow for the analysis of the dependent variable (the CWA in this study) at distinct quantiles of the distribution but only allows analysis of the dependent variable at the conditional mean (Birch and Miller, 2006). 


\section{Yusif and Ali}

\section{Results and Discussion}

This section presents the classification of students and discusses the regression results.

\section{Student classification}

Table 6 illustrates the academic classification of the 152 year 4 students based on their CWA. There are 123 males forming about $81 \%$ and 29 females who constitute roughly $19 \%$. Without doubt the gap between male and female is very significant and perhaps there is the need for an affirmative action to bridge this gap. The 2007 cohort was in the final year (except those offering medicine) and were expected to complete the BA. or BSc. by July 2011.

Table 6 reveals that $11.8 \%$ were potential first class students while $50 \%$ were likely to graduate with second class upper. Roughly $34.9 \%$ were in the second class lower range while $2.6 \%$ were likely to graduate with a pass. Only one candidate forming about $0.7 \%$ had CWA less than $45 \%$ and would probably graduate without a certificate.

The data in Table 6 show that majority of the sampled students were high performing students and this cut across all departments. For example, in Medicine out of the four less endowed students, one was in first class range, two second upper while one was in second lower. Of the 10 students in Land Economy, three were first class, four second upper and three second lower. Also out of the 21 students in Economics, five were in the first class range, 10 second upper, five second lower and one student had pass. In the Business School, out of 10 students, five were first class, four second upper and one second lower.

On the basis of the analysis above, three important facts emerged. First, in the less endowed schools, students who come top in the final SHS examinations and had obtained the basic requirements for public university entry were likely to be high ability students. Second, less endowed schools were not likely to bring out the full academic potential of students at the SHS level. Third, there was the need to identify and assist high ability students in the less endowed schools to enrol in public universities.

\section{Regression results}

Table 7 presents the results for equation 1 . The regression coefficients show that within the less endowed socio-economic group of students, the single most important predictor of academic performance in the university was the entrance score (WASSCE results). This finding is consistent with studies in industrialized countries that have investigated the performance of all students in the university (Johnes, 1997; Win and Miller, 2005; Smith and Naylor, 2005; Birch and Miller, 2006). They found that prior

Table 6: Classification of academic status of less endowed students-2007 cohort

\begin{tabular}{llcccc}
\hline CWA & STATUS & MALE & FEMALE & TOTAL & PERCENT \\
\hline $70.00-100.00$ & First Class & 16 & 2 & 18 & 11.8 \\
$60.00-69.99$ & Second Upper & 62 & 14 & 76 & 50.0 \\
$50.00-59.99$ & Second Lower & 42 & 11 & 53 & 34.9 \\
$45.00-49.99$ & Pass & 2 & 2 & 4 & 2.6 \\
$0.00-45.00$ & Below 45\% & 1 & 0 & 1 & 0.7 \\
TOTAL & & $\mathbf{1 2 3}$ & $\mathbf{2 9}$ & $\mathbf{1 5 2}$ & $\mathbf{1 0 0}$ \\
\hline
\end{tabular}

Sources: Compiled from Department and College Examination Offices, KNUST 
academic achievement was the main influence on students' university academic performance.

Again, it was found that parental background measured by parental educational attainment and parental occupation did not have any significant influence on less endowed students performance in the university. This finding is not surprising since less endowed students appear to have a very homogenous group of families and none appear to have better living condition than the other. Roughly, $73.3 \%$ had 5 or more children, $77.1 \%$ of mothers had JSS qualification or none, $31.4 \%$ of fathers were farmers while $79 \%$ of mothers were traders or farmers.

Indeed, the parents appeared to be predominantly low income people and this was unlikely to influence their children's performance through their spending. Kleinjans (2010) reported that parents with higher incomes at any given educational level might place more importance on maintaining the achieved social status and income than parents with lower incomes.

The regression was re-run but dropping the variables on fathers' and mothers' socioeconomic status. The results are presented in

Table 7: Regression results -student and parental characteristics

\begin{tabular}{lcccc}
\hline Variable & Coefficient & Std Error & t & Sig \\
\hline Gender & & & & \\
Male & 2.303 & 1.605 & 1.435 & 0.155 \\
Age & -0.728 & 0.433 & -1.682 & 0.096 \\
Siblings & 0.249 & 0.659 & 0.378 & 0.706 \\
Entrance Score & & & & \\
WASSE & -0.445 & 0.187 & -2.374 & 0.020 \\
Father qualification & & & & \\
Postsec & -0.846 & 3.949 & -0.214 & 0.831 \\
Sec & -1.748 & 4.084 & -0.428 & 0.670 \\
bec & -0.778 & 3.771 & -0.206 & 0.837 \\
Father occupation & & & & \\
Pro & -1.150 & 2.267 & -0.507 & 0.613 \\
Npro & -0.163 & 1.748 & -0.093 & 0.926 \\
Farm & -0.523 & 1.361 & -0.384 & 0.702 \\
Mother qualification & & & & \\
Postsecl & -3.369 & 4.078 & -0.826 & 0.411 \\
Secl & 0.194 & 4.090 & 0.047 & 0.962 \\
Becl & 0.000 & 3.337 & 0.000 & 1.000 \\
Mother occupation & & & & \\
Prol & 1.278 & 3.291 & 0.388 & 0.699 \\
Nprol & -0.559 & 1.662 & -0.336 & 0.738 \\
Farm1 & 0.213 & 1.554 & 0.137 & 0.892 \\
Constant & 85.177 & 11.894 & 7.162 & 0.000 \\
\hline R-Sal & & &
\end{tabular}

$R$-Squared 0.176. R-Bar-Squared $0.026 \quad$ DW-statistic 1.978 


\section{Yusif and Ali}

Table 8. It was found that university entrance score had a significant positive influence on performance at $5 \%$ significance level. This strong link vindicates the use of high school results in university admission policies (Birch and Miller, 2006) and even at KNUST, where less endowed students were given the chance to enrol, the basis for selection was still performance at the SHS. The negative sign of the coefficient is because the WASSE variable is a continuous covariate and the smaller the value the brighter the candidate, ceteris paribus.

The regression coefficients also show that being male has a significant positive influence on the performance of less endowed students at $5 \%$ level of significance. This finding contradicts Birch and Miller (2006, 2007), who found that the CWA of first year students in Australia was positively correlated with being female. However, for less endowed students in Ghana our finding was possible for one main sociological reason. Male students from less endowed schools were more likely to care less about the economic status of their course and room mates than female students. This was likely to have positive influence on male students' performance. Another important finding was that, for less endowed students, age had negative influences on their university aca- demic performance. However, the significance level was weak -i.e. $10 \%$.

\section{CONCLUSION AND RECOMMENDA- TIONS}

This paper has studied the academic performance of students from less endowed SHSs in the KNUST. Descriptive statistics show that $61.8 \%$ were academically high performing students (11.8\% was first class and $50 \%$ was second class upper). The study applied OLS to individual level data in order to determine the effect of personal characteristics and parental background measured by parental education and occupation on the performance of less endowed students in the university. It was discovered that the most important predictor of less endowed students' performance in the university was the entrance score. Regression coefficients show that the WASSE results variable was positively associated with academic performance at $5 \%$ level of significance. The regression results suggest that parental educational and occupational background did not have significant influence on academic performance of less endowed students in the university. Again, the regression results showed that, if parental background was not controlled for, being male was positively associated with the performance of less endowed students at $5 \%$ significance

Table 8: Regression results -student characteristics only

\begin{tabular}{lcccc}
\hline Variable & Coefficient & Std Error & t & Sig \\
\hline Gender & & & & \\
Male & 2.918 & 1.405 & 2.077 & 0.040 \\
Age & -0.684 & 0.370 & -1.847 & 0.068 \\
Siblings & 0.304 & 0.587 & 0.517 & 0.606 \\
Entrance Score & & & & \\
WASSE & -0.382 & 0.168 & -2.277 & 0.025 \\
Constant & 80.765 & 8.348 & 9.675 & 0.000 \\
\hline R-Squared...0.138 & R-Bar-Squared & $0.104 \quad$ DW-statistic & \multirow{2}{*}{1.887} &
\end{tabular}


Academic performance of students from less endowed senior high ... 116

level. It is recommended that future research compares the performance of students from well endowed and less endowed SHS in Ghanaian public universities.

The findings have some important policy implications for university admissions in Ghana. First, the study suggests that using SHS final examination results as a basis of admission into Ghanaian public universities was justified. However, setting the same cut-off point for students from SHS with different resource endowments may not uncover equally good students from less endowed schools. Therefore public universities' admission policy should be reviewed to capture students who come top in all less endowed schools. In this direction, the less endowed admission policy in KNUST should be strengthened and replicated in all public universities in Ghana. Thus, university admission policy with differential cut off points for less endowed and well endowed schools should be considered in the short term.

In the long term government educational policy should target accelerating the improvement of infrastructural facilities and academic staff in less endowed schools to avoid university authorities being accused of discrimination. Finally, a significant percent of less endowed students admitted were unable to enrol (Ref: Table 1). Central government, district assemblies and philanthropists should provide some financial assistance to less endowed students admitted into universities to enable them enrol and complete their studies.

\section{REFERENCES}

Addae-Mensah, I. (2000). Education in Ghana: A tool for social mobility or social stratification? Institute for Scientific and Technological Information, Accra.

Adu, K. and Opoku-Afriyie, K. J. (2002). Expenditure and Revenue Analysis of Tertiary Education Institutions in Ghana (1996-2000). Technical Report Series, The National Council for Tertiary Education, Accra
Atuahene, F. (2006). A Policy Analysis of the financing of tertiary education institutions in Ghana: An assessment of the objectives and the impact of the Ghana Education Trust Fund. PhD Dissertation, College of Education, Ohio University.

Birch, E. R. and Miller, P. W. (2006). Student outcomes at university in Australia: A quantile regression approach. Australian Economic Papers, 45 (1) :1-17

Birch, E. R. and Miller, P. W. (2007). The influence of type of high school attended on university performance. Australian Economic Papers, 46 (1) :1-15

Bratti, M. (2002). Does the choice of university matter?: A study of the differences across UK universities in life sciences students' degree performance. Economics of Education Review, 21 (5) : 431-443

Ghana Statistical Service (2007). Poverty Patterns and Trends in Ghana. GSS, Accra, Ghana.

Grove, W. A., Wasserman, T, and Grodner, A. (2006). Choosing a proxy for academic aptitude. Journal of Economic Education, 37(2) : $131-147$

Johnes, J. (1997).Inter-university variation in undergraduate non-completion rates: A Statistical analysis by subject of study. Journal of Applied Statistics, 24 (3) : 343-361

Kleinjans, K. J. (2010). Family background and gender differences in educational expectations, Economics Letters, $107: 125-127$

McIntosh, J. and Munk, M.D. (2007). Scholastic ability vs family background in educational success: evidence from Danish sample survey data. Journal of Population Economics. $20: 101-120$

Robst, J. and Keil, J. (2000). The relationship 


\section{Yusif and Ali}

between athletic participation and academic performance: Evidence from NCAA Division III. Applied Economics, 32 (5) : 547-558

Smith, J. and Naylor, R. A. (2001). Determinants of degree performance in UK universities: a statistical analysis of the 1993 student cohort, Oxford Bulletin of Economics and Statistics, 63 : 29-60

Smith, J. and Naylor, R. (2005). Schooling effects on subsequent university performance: evidence for the UK University population. Economics for Education Review, 24 (5): 549 $-562$

Summers, A. A. and Wolfe, B. L. (1977). Do schools make a difference? The American Economic Review, 67 (4) : 639-652.
The Planning Unit, Kwame Nkrumah University of Science and Technology (2010). Basic Statistics $44^{\text {th }}$ Congregation, June, 2010.

Thomas, V., Wang, Y. and Fan, X. (2001). Measuring Education Inequality: Gini Coefficients of Education. Policy Research Working Paper 2525, The World Bank, Washington D.C.

Win, R. and Miller, P. W. (2005). The Effects of Individual and School Factors on University Students' Academic Performance. The Australian Economic Review, 38 (1):1-18

Yusif, H. M., Ishak, Y. and Abu Hassan, S. (2011). Determinants of students' academic performance in senior high schools: A binary logistic approach, Journal of Science and Technology, 31(3):107-117 